\title{
Ewa Małuszyńska
}

Uniwersytet Ekonomiczny w Poznaniu

e-mail: ewa.maluszynska@ue.poznan.pl

\section{ZMIENNOŚĆ STRUKTURY \\ ZATRUDNIENIA W POLSCE \\ A STABILNOŚĆ PRZESTRZENNA SYSTEMU}

\section{CHANGES OF THE STRUCTURES \\ OF EMPLOYMENT IN POLAND \\ VS. THE SPATIAL STABILITY OF THE SYSTEM}

DOI: $10.15611 / \mathrm{pn} .2017 .465 .11$

JEL Classification: R12

Streszczenie: Wśród zjawisk zachodzących w procesie wzrostu i rozwoju systemów społeczno-gospodarczych obserwuje się zjawisko komplikowania się i specjalizacji struktur. Pomiędzy obu zjawiskami występuje sprzężenie o charakterze zwrotnym. Badania związku mechanizmu zmian strukturalnych $\mathrm{z}$ poziomem rozwoju gospodarczego mogą zapobiec lub rozwiązać pojawiające się konflikty w systemie gospodarczym oraz określać tendencje dalszego rozwoju gospodarki. Celem artykułu jest oszacowanie zmian struktury zatrudnienia w Polsce oraz związku tych zmian z poziomem rozwoju gospodarki. Cele szczegółowe opracowania są następujące: 1 . określenie zmian stopnia dywersyfikacji struktury zatrudnienia w Polsce; 2. zbadanie zależności między stopniem skomplikowania struktury a stabilnością systemu w ujęciu przestrzennym; 3. określenie zależności pomiędzy stopniem dywersyfikacji struktury a poziomem rozwoju społeczno-gospodarczego. Zakres czasowy badań obejmuje okres 1960-2014. W badaniu szczególną rolę odegrał wskaźnik nierównomierności rozkładu strukturalnego. Wykazano, że zwiększającej się złożoności obserwowanych struktur towarzyszyła zwiększająca się stabilność systemu. Potwierdzono również istnienie dodatniego związku między dywersyfikacją struktury a poziomem rozwoju społeczno-gospodarczego.

Słowa kluczowe: dywersyfikacja i podobieństwo struktur, stabilność przestrzenna systemu.

Summary: The knowledge of processes of the functioning of the economy and its changes is indispensable for the prevention and solution of conflicts and for the control and determination of tendencies in their further development. This work aims at the determination of changes of the employment structure and the relations between these changes and the level of socioeconomic development in Poland. The particular goals are: changes of the degree of complexity of the employment structure in Poland in 1960-2014; the impact of changes of the analysed structures on the stability of the system in the spatial perspective; the relation between the complexity of the structure and changes of the stability of the system, and the level of the socioeconomic development. The analysis used a non-metric measure of the similarity of structures, i.e. the cosine of the angle between the vectors representing structures 
in an n-1 dimensional space. The research was carried out on the basis of an analysis of changes of the employment structure in Poland. It was determined that in all the sets of structures under analysis, the degree of complexity was markedly increasing. At the same time, an analysis of the changes of the degree of similarity of provincial structures to the structure of Poland showed a spatial similarity, which in compliance with the adopted definition is tantamount to an increase in stability. In this way it was shown that the increasing complexity of the observed structures was accompanied by a growing stability of the system. It was also confirmed that there exists a clear positive relation between a degree of diversification of structures, and the level of socioeconomic development.

Keywords: diversification and similarity of structures, spatial stability of the system.

\section{Wstęp}

Wśród wielu zjawisk zachodzących w procesie wzrostu i rozwoju systemów społeczno-gospodarczych obserwuje się jego związek z komplikowaniem się i specjalizacją struktur. Nieodpowiednie struktury mogą doprowadzić do niefunkcjonalności systemu ${ }^{1}$. Niefunkcjonalność systemu będzie z kolei wymuszać zmiany strukturalne. Związek pomiędzy wzrostem i rozwojem gospodarczym a zmianami strukturalnymi ma więc charakter sprzężenia zwrotnego. Badania związku mechanizmu zmian strukturalnych $^{2} \mathrm{z}$ poziomem rozwoju gospodarczego są konieczne dla zapobiegania powstawaniu i rozwiązywania pojawiających się w systemie gospodarczym konfliktów oraz sterowania i określania tendencji dalszego rozwoju gospodarki. W rozważaniach nad związkiem pomiędzy procesem zmian strukturalnych i wzrostem gospodarczym najczęściej zakładano, co było następnie potwierdzane wynikami licznych badań, że wzrost i rozwój gospodarczy w skali kraju, regionu lub miasta związane są z komplikowaniem się struktur [Domański 2000; Lee 2014]. Wyniki dalszych badań wykazały jednak, że podczas gdy wzrostowi PKB/os. w początkowej fazie rozwoju gospodarki rzeczywiście najczęściej towarzyszy wzrost zróżnicowania struktury, po osiągnięciu pewnego poziomu rozwoju, poziomu krytycznego, widoczny jest proces specjalizacji (koncentracji, spadku dywersyfikacji) struktury. Procesowi wzrostu gospodarczego towarzyszą więc dwa etapy dywersyfikacji struktury [Imbs, Wacziarg 2003]³. Krzywa zależności pomiędzy PKB/os. a dywersyfikacją struktury gospodarczej jest wówczas U-kształtna ${ }^{4}$. „Drugi etap jest jednak bardziej dyskusyjny [...] kontynuacja wzrostu na wysokim poziomie rozwoju nie wiąże

${ }^{1}$ Niefunkcjonalność systemu oznacza niezaspokojenie lub częściowe zaspokojenie popytu na określone funkcje lub dobra.

${ }^{2} \mathrm{~W}$ poznawaniu mechanizmu zmian strukturalnych, poza pomiarem zmian stopnia dywersyfikacji struktur, wyróżnić można badania dynamiki zmian struktury, stabilności kierunku zmian strukturalnych i oddalania się struktury od postaci wyjściowej.

${ }^{3}$ Punkt krytyczny oszacowany został przez autorów na 9000\$/os. w cenach z 1985 r.

${ }^{4} \mathrm{Na}$ osi Y przedstawione są wartości wskaźnika dywersyfikacji. Wzrastająca wartość wskaźnika oznacza spadek stopnia dywersyfikacji struktury. 
się z respecjalizacją [spadkiem dywersyfikacji, E.M.], a raczej z utrzymaniem wysoce zróżnicowanej struktury gospodarki. Należy też podkreślić, że kształt krzywej dywersyfikacji obrazuje pewną ogólną tendencję obserwowaną w procesie wzrostu gospodarczego, a niekoniecznie ścieżkę, którą musi podążać każdy kraj rejestrujący wzrost dochodu na mieszkańca" [Parteka 2015].

Zagadnienie komplikowania się struktur pojawia się również w pracach dotyczących stabilności systemów, w tym systemów społeczno-gospodarczych. Przez stabilność rozumie się nie tylko niezmienność [Gruszczyńska, Gruszczyński 1988; Mucha 1990], lecz również zbieżność do stanu równowagi [Gościński 1982], tj. stanu, w którym system pozostaje dowolnie długo przy braku zakłóceń, lub stanu, w którym następuje wzajemne dostosowanie się podsystemów w zakresie ich elementów i powiązań. W kontekście przestrzennym stabilność to zbieżność do stanu równowagi oznaczającego ten sam lub mniejszy stopień przestrzennego zróżnicowania w porównaniu z układem odniesienia. W badaniach nad stabilnością systemów stwierdza się również, że warunkiem wzrostu i rozwoju każdego systemu, począwszy od systemów biologicznych, poprzez fizyczne, chemiczne, ekonomiczne, społeczne itd., są systematyczne zmiany struktury prowadzące w kierunku jej komplikowania się i powstawania układów o nowych właściwościach ${ }^{5}$. Inaczej mówiąc, podstawową przyczyną zmian zachodzących $\mathrm{w}$ strukturze jest naturalne dążenie każdego systemu do zachowania stabilności jako gwarancji istnienia i rozwoju. Celem artykułu jest oszacowanie zmian struktury zatrudnienia w Polsce oraz związku tych zmian z poziomem rozwoju gospodarki. Cele szczegółowe opracowania są następujące: 1. określenie zmian stopnia dywersyfikacji struktury zatrudnienia w Polsce; 2 . zbadanie zależności między stopniem skomplikowania struktury a stabilnością systemu w ujęciu przestrzennym; 3. określenie zależności pomiędzy stopniem dywersyfikacji struktury a poziomem rozwoju społeczno-gospodarczego. Zakres czasowy badań obejmuje okres 1960-2014.

\section{Metoda badawcza}

W badaniu wykorzystano strukturę zatrudnienia wszystkich województw Polski wg sekcji działalności gospodarczej w latach 1960-1972 i 1975-1989 oraz strukturę pracujących w okresie 2002-20146. W dwóch pierwszych okresach w strukturze zatrudnienia wyróżniono 10 sekcji, w latach 2002-2014 - 12 sekcji ${ }^{7}$. Dla wszystkich okresów obliczono coroczne wartości wskaźnika dywersyfikacji struktury oraz

\footnotetext{
${ }^{5}$ W artykule wykorzystano wyniki badań przeprowadzonych dla okresu 1960-1989, przedstawionych w: [Małuszyńska 1993].

${ }^{6}$ Podział na okresy: 1960-1972, 1975-1989 i 2002-2014 związany jest ze zmianami podziału administracyjnego Polski, zmianami PKD oraz dostępnością danych. Strukturę pracujących przyjęto dla odzwierciedlenia zmian, które nastąpiły w gospodarce po roku 1989, oraz ze względu na dostępność porównywalnych danych dla dłuższego okresu czasu.

7 Zgodnie z PKD obowiązującą od 2007 r.
} 
wskaźnika podobieństwa struktury [Kukuła 1989] każdego województwa do struktury Polski, niezbędnego do określenia stabilności przestrzennej systemu. W obu przypadkach wykorzystano wskaźnik nierównomierności rozkładu strukturalnego, będący zmodyfikowaną formułą cosinusowego współczynnika zbieżności struktur, którego wartości mieszczą się w przedziale $(0,1)$. Wartość równą jeden przyjmuje on, gdy struktury są identyczne, zdąża do zera wraz ze zmniejszaniem się podobieństwa struktur. Wskaźnik zbieżności przyjmuje postać:

$$
L=\left[1-\left(\frac{\sum_{i=1}^{n} f_{i}^{(1)}-f_{i}^{(2)}}{\sum_{i=1}^{n} f_{i}^{(1)^{2}} \sum_{i=1}^{n} f_{i}^{(2)^{2}}}\right)^{2}\right]^{\frac{1}{2}},
$$

gdzie: $f_{i}^{(1)}$ jest $i$-tym wskaźnikiem struktury pierwszej, a $f_{i}^{(2)} i$-tym wskaźnikiem struktury drugiej.

Traktując rozkład równomierny jako wzorzec, za pomocą wskaźnika zbieżności struktur opisać można również stopień nierównomierności danego rozkładu empirycznego. Jako strukturę bazową przyjmujemy wówczas równomierny rozkład struktury, inaczej rozkład jednostajny, w którym udziały procentowe poszczególnych elementów struktury są takie same i wynoszą 100/n. Wykorzystywany w ten sposób wskaźnik zbieżności struktur, traktowany teraz jako wskaźnik dywersyfikacji struktury, przyjmuje postać:

$$
L^{\prime}=\left[1-\frac{10000}{n \sum_{i=1}^{n} f_{i}^{2}}\right]^{\frac{1}{2}} .
$$

Wskaźnik ten zachowuje przy tym bez zmian swoją podstawową własność, jaką jest wartość równa zero przy pełnej zgodności porównywanych struktur, w tym przypadku zgodności struktury badanej z rozkładem równomiernym. Ograniczeniem tak obliczanego wskaźnika dywersyfikacji jest zależność jego maksymalnej wartości od liczby elementów struktury $n$, np. gdy udział jednego z elementów struktury równa się $100 \%$, a pozostałych $0 \%$, przy minimalnej liczbie elementów, tzn. gdy $n=2$, wartość ta wynosi 0,707 . Wraz ze wzrostem $n$ wartość wskaźnika dywersyfikacji szybko wzrasta, zbliżając się do jedności. I tak np. dla $n$ równego 100 wartość maksymalna wynosi 0,995 , a dla $n$ równego $1000-0,999$. W sytuacji gdy mamy do czynienia z różną ilością elementów tworzących porównywane struktury, możliwe jest wykorzystanie wartości procentowych, gdzie 100\% stanowi maksymalna wartość wskaźnika. 


\section{Zmienność stopnia dywersyfikacji struktury zatrudnienia i struktury pracujących w Polsce}

Zmienność przestrzenną i czasową stopnia dywersyfikacji struktury zatrudnienia i pracujących w Polsce w latach 1960-2014 wykazuje charakteryzują wyraźne prawidłowości. Ze względu na przeprowadzenie badań na pełnych zbiorach i w długim okresie, prawidłowości te $\mathrm{z}$ dużym prawdopodobieństwem można uznać za wysoce istotne. Przy stosunkowo małych wahaniach badaną strukturę charakteryzuje spadek wartości wskaźnika dywersyfikacji, czyli wyrównywanie się udziałów jej poszczególnych elementów (wzrost skomplikowania). Potwierdzają to wartości średnie oraz oszacowane modele trendu. W drugim i trzecim z analizowanych okresów wartości wskaźnika dywersyfikacji miały silniejszą niż w pierwszym okresie tendencję spadkową, co jest wyrazem znaczniejszego wzrostu stopnia zróżnicowania struktury Polski (rys. 1).

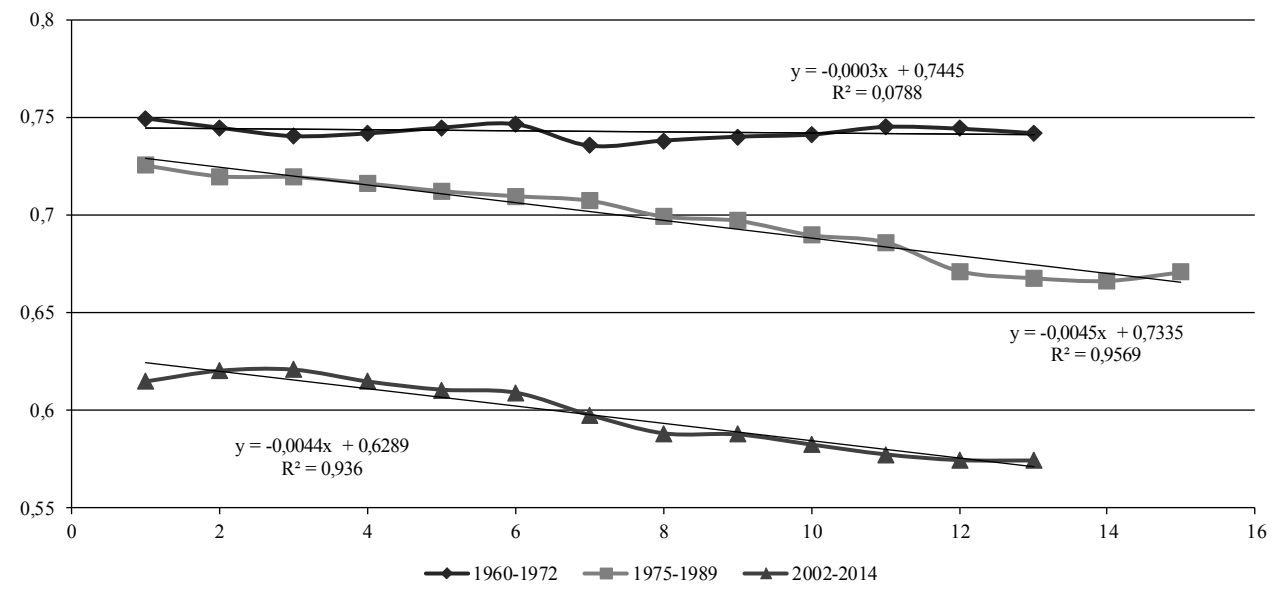

Rys. 1. Dywersyfikacja struktury zatrudnienia w latach 1960-1989 i struktury pracujących w okresie 2002-2014 w Polsce

Źródło: obliczenia własne na podstawie danych GUS.

Średnia wartość wskaźnika dywersyfikacji w kolejnych okresach wynosiła odpowiednio: $0,74, \mathrm{tj} .78 \%$ wartości maksymalnej; $0,7, \mathrm{tj}$. 73\% wartości maksymalnej oraz $0,6, \mathrm{tj} .63 \%$ wartości maksymalnej ${ }^{8}$.

Analiza przestrzenna stopnia zróżnicowania struktury zatrudnienia/pracujących wykazała istotne zróżnicowanie regionalne. W pierwszym $\mathrm{z}$ analizowanych okresów maksymalna wartość wskaźnika dywersyfikacji równa 0,85 wystąpiła w woj. kato-

${ }^{8}$ Dla $n=10$ maksymalna wartość wskaźnika dywersyfikacji równa się 0,948 , dla $n=13$ natomiast 0,957 . 
wickim, minimalna, równa 0,51, w woj. olsztyńskim. W latach 1975-1989 wartość maksymalna i minimalna wynosiła: $0,83 \mathrm{w}$ woj. katowickim i $0,51 \mathrm{w}$ woj. koszalińskim, a w latach 2002-2014 - 0,77 w woj. lubelskim i 0,5 w woj. zachodniopomorskim. Maksymalna wartość wskaźnika dywersyfikacji w całym analizowanym okresie występowała w woj. katowickim, co wskazywało na największą w skali Polski koncentrację zatrudnienia $\mathrm{w}$ tym regionie, tj. wyraźną przewagę udziału jednego (lub kilku) sektorów gospodarki nad pozostałymi.

W pierwszym i trzecim z obserwowanych zbiorów występują województwa charakteryzujące się, podobnie jak cały kraj, tendencją wzrostową stopnia skomplikowania struktury (spadek wartości wskaźnika), tendencją malejącą (wzrost wartości wskaźnika) lub bez wyraźnego kierunku zmian dywersyfikacji struktury. W okresie 1975-1989 natomiast wszystkie województwa charakteryzował wzrost stopnia skomplikowania struktury zatrudnienia.

\section{Dywersyfikacja struktury zatrudnienia i struktury pracujących a stabilność przestrzenna systemu}

Konsekwencją zmian regionalnych struktur zatrudnienia i struktury pracujących o różnym natężeniu, kierunkach i stabilności tych kierunków może być wzrost, zmniejszenie się lub niezmienność ich zróżnicowania przestrzennego. Uzyskanie informacji o zmianach zróżnicowania przestrzennego daje możliwość przeprowadzenia analizy zmian stabilności systemu w ujęciu przestrzennym. Układem odniesienia w kolejnych okresach była struktura zatrudnienia i pracujących w Polsce. Wartości wskaźników oddalenia struktur regionalnych od struktury Polski obliczono dla każdego roku analizowanych okresów. Zbieżność przestrzenną struktur zbadano, analizując różnice pomiędzy maksymalnymi i minimalnymi wartościami podobieństwa struktur oraz odchylenia standardowe tych wskaźników w kolejnych latach. Dla otrzymanych wartości oszacowano funkcję trendu. Przebieg i postać funkcji trendu różnic pomiędzy maksymalną i minimalną wartością wskaźnika w dwóch pierwszych okresach potwierdził zbliżanie się struktur wojewódzkich do struktury Polski, a więc zbieżność przestrzenną tych struktur (rys. 2). Funkcja trendu obliczona dla lat 2002-2014 nie potwierdziła wcześniejszych tendencji. Jej przebieg wskazuje więc na zwiększoną niestabilność systemu. W analizowanym zbiorze danych dla lat 2002-2014 wartość maksymalna i minimalna w dużym stopniu odbiegały od wartości pozostałych ${ }^{10}$. Po ich usunięciu ponownie obliczono różnice pomiędzy największą i najmniejszą wartością wskaźnika oddalenia struktur wojewódzkich od struktury Polski. Przebieg funkcji trendu i jej postać dla tak obliczonych wartości wskazuje na

\footnotetext{
9 Pojęcie stabilności systemu w ujęciu przestrzennym wyjaśniono we wstępie.

${ }^{10}$ Wartość maksymalna w całym okresie występowała w woj. lubelskim, wartość minimalna w woj. kujawsko-pomorskim.
} 


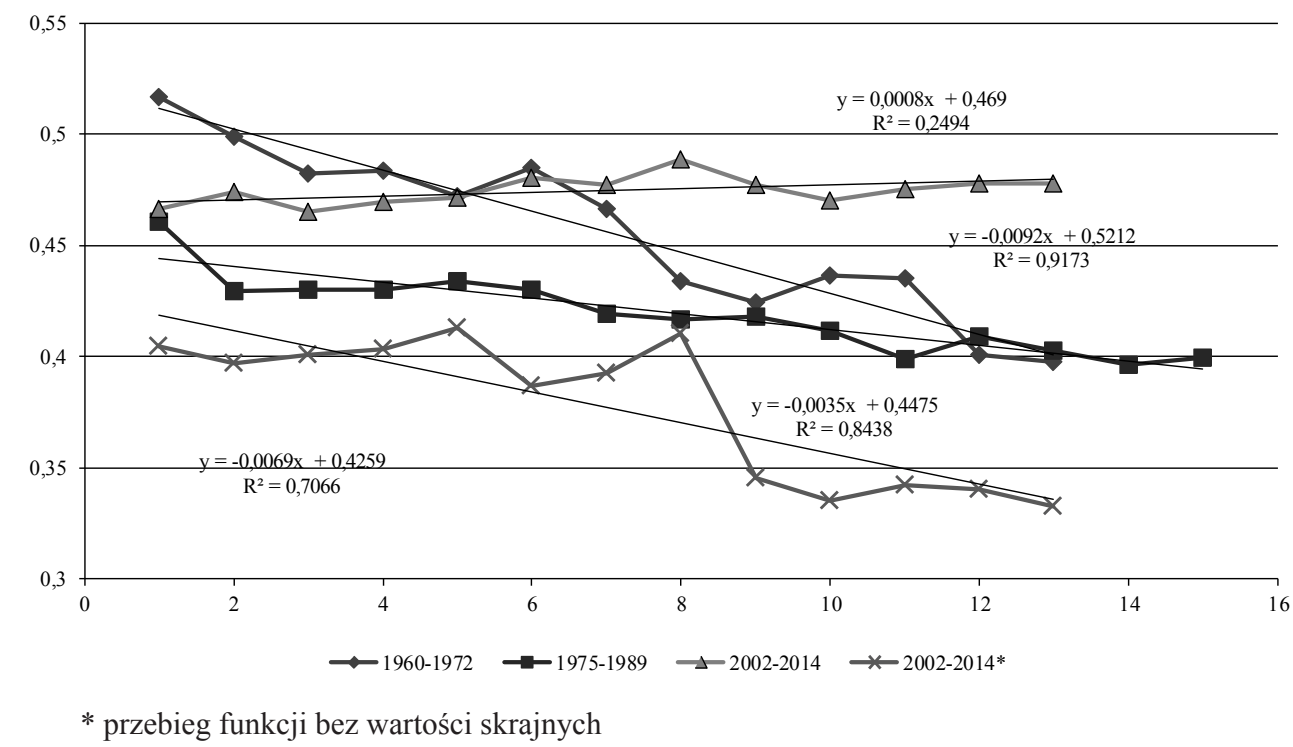

Rys. 2. Różnica między maksymalnym i minimalnym oddaleniem struktur wojewódzkich od struktury Polski

Źródło: obliczenia własne.

zbliżanie się struktury województw do struktury całego $\mathrm{kraju}^{11}$. Przebieg funkcji trendu odchyleń standardowych wskaźnika oddalenia struktur od struktury Polski we wszystkich trzech przypadkach wskazuje na zwiększanie się podobieństwa struktur, co ponownie potwierdza stabilność przestrzenną systemu, która w ostatnim $\mathrm{z}$ analizowanych okresów jest jednak słabsza niż w okresach wcześniejszych.

\section{Dywersyfikacja struktury zatrudnienia i pracujących a poziom rozwoju gospodarczego $\mathrm{w}$ Polsce}

Nadrzędnym celem zmian zachodzących w systemach społeczno-gospodarczych, w tym również zmian strukturalnych, jest osiąganie coraz wyższego poziomu rozwoju gospodarczego lub przynajmniej niedopuszczenie do jego obniżenia. Przyjmując, że bardziej korzystne dla rozwoju gospodarczego są systemy bardziej złożone, czyli systemy o bardziej zróżnicowanej strukturze, przeprowadzono badanie współzależności poziomu rozwoju społeczno-gospodarczego i stopnia dywersyfikacji struktur w latach 1960, 1961, 1970, 1976, 1986 oraz w okresie 2002-2014 ${ }^{12}$. Poziom rozwoju

${ }^{11}$ Należy pamiętać, że wskaźnik podobieństw (oddalenia) struktury określa zróżnicowanie udziałów poszczególnych elementów struktury. Na jego podstawie nie da się jednak określić, czy np. największe lub najmniejsze udziały dotyczą tych samych sektorów gospodarki.

${ }_{12}$ Dobór poszczególnych lat w pierwszych dwóch okresach wynikał z dostępności danych o DN w układzie regionalnym. 
województw wyrażono wysokością DN/os. w dwóch pierwszych okresach i PKB/ os. w latach 2002-2014. W analizowanych latach 1960-1986 wszystkie wartości istotnych statystycznie wskaźników korelacji były dodatnie, co oznacza, że wyższy poziom DN/os. osiągały województwa o większej koncentracji zatrudnienia. Taka sytuacja wskazywałaby na „nieracjonalność” kierunku zmian dywersyfikacji struktur regionalnych. $\mathrm{Z}$ oszacowanych funkcji regresji wynika jednak, że większa koncentracja zatrudnienia przynosiła od $1970 \mathrm{r}$. coraz mniejsze efekty w postaci przyrostu DN/os. ${ }^{13}$ Można więc przyjąć, że regiony reorganizowały swoją strukturę zgodnie z ogólnie obserwowanymi, uznawanymi za korzystne tendencjami komplikowania się struktur. Prawidłowość takiego podejścia potwierdzają wyniki badań przeprowadzonych dla okresu 2002-2013. Korelacja pomiędzy wskaźnikiem dywersyfikacji struktury pracujących i PKB/os. w województwach Polski jest w przeciwieństwie do poprzednich okresów ujemna. Większe zróżnicowanie struktury, a więc zmniejszenie się dominacji poszczególnych sektorów na rzecz innych rodzajów działalności wpływa na większy przyrost PKB/osobę. Podobnie jak poprzednio, najlepiej dopasowaną funkcją regresji opisującą kształt zależności między analizowanymi zmiennymi jest funkcja potęgowa. Stopień wyjaśnienia zmiennej PKB/os. mierzony wartością $\mathrm{R}^{2}$ wynosi od $29 \%$ do $50 \%$. Wzrost wartości wykładnika potęgowego, większego od jedności, w kolejnych latach jest odbiciem sytuacji, w której coraz większej dywersyfikacji struktury towarzyszy większy niż proporcjonalnie i wzrastający wzrost PKB/osobę. Nawiązując do etapów dywersyfikacji struktury w procesie wzrostu gospodarczego, można stwierdzić, że Polska znajduje się w pierwszym etapie tego procesu, w którym wzrostowi gospodarczemu towarzyszy wzrost dywersyfikacji struktury.

\section{Zakończenie}

Spadek wartości wskaźnika dywersyfikacji we wszystkich przyjętych do badania okresach jest wyrazem procesu komplikowania się analizowanych struktur, co jest korzystne i bezpieczne dla gospodarki. Pomimo zmniejszania się tych wartości średnie wskaźniki dywersyfikacji są wciąż wysokie dla całych zbiorów. Jednocześnie analiza zmian stopnia podobieństwa struktur wojewódzkich do struktury Polski wykazała zbieżność przestrzenną, co zgodnie z przyjętą definicją oznacza wzrost stabilności systemu. Można więc powiedzieć, że wzrostowi złożoności obserwowanych struktur towarzyszyła zwiększająca się stabilność systemu. Potwierdzono również istnienie związku między dywersyfikacją struktury a poziomem rozwoju społeczno-gospodarczego. W okresie 1960-1989 widoczna była dodatnia korelacja pomiędzy DN/os. i stopniem dywersyfikacji struktury zatrudnienia. Malejące wykładniki potęgowe funkcji regresji oznaczały jednak zmniejszanie się wpływu stopnia skompliko-

${ }^{13}$ Wskazywały na to zmniejszające się wartości wykładników potęgowych funkcji regresji. Z wyjątkiem $1961 \mathrm{r}$. funkcja potęgowa $\mathrm{y}=\mathrm{ax}^{\mathrm{b}}$ była najlepiej dopasowaną funkcją. 
wania struktury na wzrost DN/os. W okresie 2002-2013 natomiast korelacja pomiędzy wielkością $\mathrm{PKB} /$ os. i stopniem dywersyfikacji struktury pracujących była ujemna. Większe od jedności i zwiększające się wartości wykładników potęgowych funkcji regresji wskazują, że przyrost zmiennej zależnej, tj. PKB/os. w stosunku do przyrostów zmiennej niezależnej, jaką jest stopień dywersyfikacji struktury pracujących, jest rosnący.

Wiedza na temat obserwowanych tendencji powinna być wykorzystywana $\mathrm{w}$ przypadku podejmowania decyzji dotyczących procesów zmian strukturalnych systemów społeczno-gospodarczych. Działania hamujące proces dywersyfikacji struktur na obecnym poziomie rozwoju gospodarczego Polski, nawet jeżeli przynoszą pożądane efekty w danym momencie, w wyniku niedostosowania struktury do wzrastającego zapotrzebowania na różnorodne zasoby i funkcje zmniejszają stabilność systemu i mogą powodować zakłócenia w jego dalszym rozwoju, a nawet jego zniszczenie.

\section{Literatura}

Domański R., 2000, Miasto innowacyjne, Studia KPZK, t. CIX, Wydawnictwo Naukowe PWN, Warszawa.

Gościński J., 1982, Sterowanie i planowanie. Ujęcie systemowe, PWE, Warszawa.

Gruszczyńska B., Gruszczyński M., 1988, Metoda analizy stabilności struktury, Wiadomości Statystyczne, z. 1.

Imbs J., Wacziarg R., 2003, Stages of diversification. The American Economic Review, vol. 93, no 1, s. 63-86.

Kukuła K., 1989, Statystyczna analiza strukturalna i jej zastosowanie w sferze uslug produkcyjnych dla rolnictwa, Zeszyty Naukowe AE w Krakowie, Monografie, nr 89.

Lee N., 2014, Grim down South? The determinants of Unemployment Increases in British Cities in the 2008-2009 Recession, Routledge, Regional Studies, vol. 48, no 11.

Małuszyńska E., 1993, Regionalne zróżnicowanie zmienności struktur gospodarczych, Wydawnictwo AE w Poznaniu, Zeszyty Naukowe, Seria II, z. 132, Poznań.

Mucha Z., 1990, Metoda analizy szeregu czasowego struktury, Przegląd Statystyczny, t. 37, s. 78.

Parteka A., 2015, Dywersyfikacja handlu zagranicznego a rozwój gospodarczy, Wydawnictwo Naukowe PWN. 